\title{
イムノグロブリン $\mathrm{E}$ 抗体固定化オプトロードによる アレルゲンの検出
}

\author{
中村 徳幸，松 永 是 ${ }^{\circledR *}$
}

(1990 年 7 月 10 日受理)

\begin{abstract}
イムノグロブリン E (IgE) 抗体固定化オプトロードを用いてアレルゲンの検出を行った. 光ファイ バー末端に IgE 抗体を固定化した膜を装着し，アレルゲン及び蛍光色素標識アレルゲンを競合法によ り反応させ，蛍光強度を測定することによりアレルゲンの濃度を求めた. アレルゲン濃度が 0 のとき に得られる蛍光強度を $100 \%$ とした相対蛍光強度はアレルゲン濃度が増加するにつれ減少した. 蛍光 色素標識アレルゲンの濃度を $5 \mathrm{ng} \mathrm{ml}^{-1}$ にした場合, $0 \sim 10 \mathrm{ng} \mathrm{ml}^{-1}$ のアレルゲン濃度範囲において相 対蛍光強度は直線的に減少し, 相対蛍光強度からアレルゲンの濃度が推定可能であった. 又, 抗体固定 化膜から蛍光色素標識アレルゲンの酸による解離を 10 回繰り返しても蛍光強度は初期の $15 \% し か$ 低 下しなかった。
\end{abstract}

\section{1 緒言}

生体内には醉素, 抗体, 結合タンパク質など特定物質 に対する分子認識機能の優れた物質が存在する. 抗体 は, 生体内に外部から侵入した異種タンパク, 細菌, ウ イルス，薬剤などのアレルゲン（抗原）に対して産生さ れる.このアレルゲンを排除し，自己を防御する免度応 答において，ある条件のもとでは全身又は局所に障害を 起こす場合がある。この障害作用はアレルギー反応と呼 ばれており，花粉症や食物アレルギーなどがその代表的 なものとして知られている.

現在，これらの反応にかかわるアレルゲンの同定，あ るいはイムノグロブリン E（IgE）抗体の検出及び定量 には，皮膚テスト(プリック，スクラッチ）やアレルゲ ン吸入誘発試験, 及び RAST (radio allergosorbent test）などが行われている1).しかし，皮膚テストやア レルゲン吸入誘発試験では実験対象動物あるいは患者が アナフィラキシーショックを起こす場合がある. 又, RAST では放射性同位元素を用いるため, 感度には優 れているものの, 操作が煩雑なこと, 使用する試薬が高 価であり，その処理などについて問題がある。このた め, 新たな検出法, 定量法が望まれている，既に著者ら は, 好塩基球を用いる電極型アレルギーセンサーについ て報告した2). 好塩基球にアレルゲンが結合すると細胞

* 東京農工大学工学部物質生物工学科: 184 東京都小金 井市中町 2-24-16
内のセロトニンが放出される．このセロトニンの減少を 電気化学的に測定することでアレルゲンを検出した。こ の方法は好塩基球のアレルギ一応答を利用したものであ る. 実際には, 好塩基球の表面の IgE とアレルゲンの 反応によりセロトニンの放出が起きている．ここでは， $\operatorname{IgE}$ とアレルゲンとの反応をそのままとらえることを試 みた。

抗原抗体反応のアフィニティーを利用したオプトロー ド型のセンサーが報告されているが, 測定対象はグル コースであった ${ }^{3) 4)}$. Tromberg らにより, 蛍光色素標識 抗体と抗体との競合法から抗イムノグロブリン $\mathrm{G}$ (IgG) 抗体が検出された ${ }^{5)}$. 又最近, ヒト血清アルブミ ンをモデルアレルゲンとして測定するセンサーが

Bright らにより開発された6).

そこで本研究では, 新たなアレルゲンの検出法の開発 を目的として, IgE の抗原抗体反応を利用したオプト ロード型のアレルギーセンサーを作製し，アレルゲンの 測定について検討した.

\section{2 実験}

\section{$2 \cdot 1$ 試 薬}

$N$-(6-アミノヘキシル)-3-アミノプロピルトリメトキ シシラン $(N$-3-APTMS $)$ はトーレ・シリコーンより譲 り受けたものを用いた。 ウシ血清アルブミン（BSA）, $\operatorname{IgE}$ は生化学工業より, 3-アミノプロピルトリエトキシ シラン（3-APTES）は東京化成工業よりそれぞれ購入 
した．他の試薬は市販の特級品を用いた，又，実験には． 脱イオンー蒸留水を用いた。

\section{$2 \cdot 2$ モデルアレルゲンの調製}

モデルアレルゲンとして, 本研究ではジニトロフェニ ル化したウシ血清アルブミン（DNP-BSA）を用いた。 2,4-ジニトロベンゼン-1-スルホン酸ナトリウム (DNBS) とBSA を混合し, Eisen らの方法7に従って 調製した.

\section{$2 \cdot 3$ 蛍光色素標識アレルゲンの調製}

$5 \mathrm{ml}$ のホウ酸塩緩衝液（ $\mathrm{pH} 9.0 ）$ にアロフィコシア ニン ( $\mathrm{APC}) を 10 \mu \mathrm{g} \mathrm{ml}^{-1}$ になるように加え, 更に DNBS を添加し, 暗状態下で 18 時間, $25^{\circ} \mathrm{C}$ でかき混 ぜ, 反応を行った，反応終了後，1000 倍容のリン酸塩 緩衝生理食塩水 (PBS; pH 7.4) で 2 日間にわたり $4^{\circ} \mathrm{C}$ で透析を行い，未反応の DNBS を取り除いた. 蛍光色 素で標識したアレルゲンであるジニトロフェニル化され たアロフィコシアニン（DNP-APC）は $4^{\circ} \mathrm{C}$ ，暗状態で 保存した.

\section{$2 \cdot 4$ 抗体固定化膜の調製}

抗体固定化膜としてセルロース透析膜とアセチルセル ロース膜の 2 種類について検討した. セルロース透析 膜 (孔径 $24 \AA$ A $5 \mathrm{~cm}^{2}$ ) は洗浄後, $1 \mathrm{ml}$ の 3-APTES 又 は $N$-3-APTMS に浸し, $25^{\circ} \mathrm{C}$ で 10 分間放置した.こ の膜をまず水で, 次に PBS で, それぞれ洗浄した後, $2.5 \%$ のグルタルアルデヒドを含む $2 \mathrm{ml}$ の PBS 中に浸 漬させ $25^{\circ} \mathrm{C}$ で 1 時間放置した。

一方，アセチルセルロース膜は以下のように調製し た. $60 \mu \mathrm{l}$ の 1,8-ジアミノ-4-アミノメチルオクタン（ト リアミン) と $40 \mu \mathrm{l}$ の $2.5 \%$ グルタルアルデヒドに 80 $\mathrm{mg}$ の三酢酸セルロースを加え, $2 \mathrm{ml}$ のジクロロメタン に溶解させ，テフロン板上に広げ， $25^{\circ} \mathrm{C}$ で 1 日乾燥さ せた。形成した膜は $5 \mathrm{~cm}^{2}$ になるように裁断し，1\%の グルタルアルデヒド溶液中で 1 時間インキュベートさ せた。このようにして調製した膜は PBS で洗浄後, 1 $\mathrm{ml}$ の抗体溶液 $\left(100 \mu \mathrm{g} \mathrm{ml}^{-1}\right)$ 中, $4^{\circ} \mathrm{C}$ で 12 時間放置 した. 抗体固定化膜は $0.1 \mathrm{~mol} \mathrm{l}^{-1}$ の濃度の水素化ホウ 素ナトリウムを含むPBS 中で還元処理を行った. 抗体 溶液中の夕ンパク質をローリー法 ${ }^{8)} よ り$ 求め, 固定化前 後の量から膜上に固定化された抗体の量を算出した. 調 製した抗体固定化膜はPBS で洗浄後, $4^{\circ} \mathrm{C}$ で保存し た.

Table 1 にその固定化量についてまとめた. セルロー
Table 1 Immobilization of IgE on membrane

\begin{tabular}{ccc}
\hline Membrane & $\begin{array}{c}\text { Silane coupling } \\
\text { reagent }\end{array}$ & $\begin{array}{c}\text { Amount of } \\
\text { immobilized } \\
\text { IgE/ } \mu \mathrm{g} \mathrm{cm}^{-2}\end{array}$ \\
\hline GDM & 3-APTES & 0.50 \\
CDM & $N$-3-APTMS & 0.68 \\
AM & - & 0.60 \\
\hline
\end{tabular}

CDM : cellulose dialysis membrane; AM : acetylcellulose membrane; 3-APTES : 3-aminopropyltriethoxysilane; $N$-3-APTMS : $N$-(6-aminohexyl)-3aminopropyltrimethoxysilane

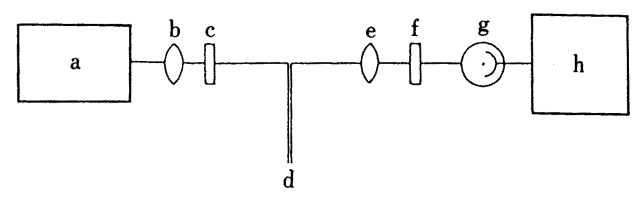

Fig. 1 Schematic diagram of an optrode system a) light source; B) focusing lens; c) filter; d)
sensing probe; e) collimating lens; f) filter; g)
photomultiplier tube; h) photomultiplier read-
out

又透析膜を N-3-APTMS で処理し, 酵素を固定化した 膜が他の膜に比べ，1.2 1.5 倍多く固定化されているこ とが分かった。これは, シラン化剤である $N$-3-APTMS の疎水基と抗体の結合部分との親和性が 3-APTMS に 比べて高かったものと考えられる. 又, 膜の透明度など の点から考慮して，N-3-APTMS で処理したセルロー ス透析膜を以後の実験で用いた。

\section{$2 \cdot 5$ 実験装置}

本研究で用いた実験装置の模式図をFig. 1 に示し た. 光源であるへリウムーネオン $(\mathrm{He}-\mathrm{Ne})$ レーザー (東芝製, $2 \mathrm{~mW}$ ) から出た光は光ファイバー（三菱レ イヨン製, 径 $600 \mu \mathrm{m})$ を通り, 干渉フィルターを介し てセンシングプローブへ達する. 検出光は抗体固定化膜 を装着したプローブから再び光ファイバーを通り, 光電 子増倍管（浜松ホトニクス, R1477）で蛍光強度を測定 した.

\section{$2 \cdot 6$ オプトロードによるアレルゲンの測定}

アレルゲンの測定は競合法により行った. IgE 抗体固 定化膜を光ファイバーの先端に装着し，このセンシング プローブを $\mathrm{PBS}(\mathrm{pH} 7.4) 1 \mathrm{ml}$ に浸漬させた. モデル アレルゲン (DNP-BSA), 及び蛍光色素標識アレルゲ 


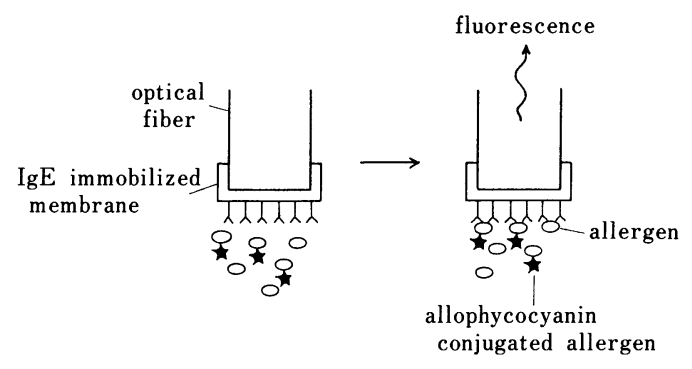

Fig. 2 Measurement of allergen using an optrode

ン（DNP-APC）を PBS 中に加え，競合法により膜上 に固定化した抗体と反応させ，抗原抗体反応により特異 的に結合したアロフィコシアニン標識アレルゲン由来の 蛍光を, 励起光 $620 \mathrm{~nm}$, 検出光 $660 \mathrm{~nm}$ で測定した.

Fig. 2 にオプトロードによるアレルゲン測定の模式図 を示した。

\section{3 結果及び考察}

\section{$3 \cdot 1$ 測定条件の検討}

アレルゲン測定の原理は, アレルゲン及び蛍光色素標 識アレルゲンを，センサープローブの膜上に固定化した $\mathrm{IgE}$ と競合法により反応させ, 得られた相対蛍光強度か らアレルゲン濃度を求めるのである.

このオプトロードシステムの測定条件について，まず $\mathrm{pH}$ の影響について検討した. PBS の $\mathrm{pH}$ を6.0〜9.0 まで変化させて, PBS $1 \mathrm{ml}$ 中にアレルゲン及び蛍光色 素標識アレルゲンをそれぞれ $50,100 \mathrm{ng} \mathrm{ml}^{-1}$ の濃度に なるように加え, 20 分間反応を行った. $\mathrm{pH}$ が上昇す ると共に, 蛍光強度もしだいに高くなることが示され た. pH 7.4のときに蛍光強度の増加が最も高くなっ た.そこで, $\mathrm{pH} 7.4$ のときに得られた蛍光強度を $100 \%$ として, 各 $\mathrm{pH}$ における相対蛍光強度を Fig. 3 に示した. Fig. 3 に示したように $\mathrm{pH}$ が 8.0 を超えると 蛍光強度が著しく低下することが明らかになった。

又, 測定時の温度による蛍光強度への影響について調 ベたところ， $15 \sim 30^{\circ} \mathrm{C}$ の温度範囲において蛍光強度は $5 \%$ の範囲内で安定なことが示された。そこで，測定時 の $\mathrm{PBS}$ の $\mathrm{pH}$ を 7.4 に, 又, 温度を $27^{\circ} \mathrm{G}$ に設定し た.

\section{$3 \cdot 2$ オプトロードによるアレルゲンの測定}

PBS $1 \mathrm{ml}$ 中にアレルゲン, 蛍光色素標識アレルゲン をそれぞれ $50,100 \mathrm{ng} \mathrm{ml}^{-1}$ になるように加えたとこ

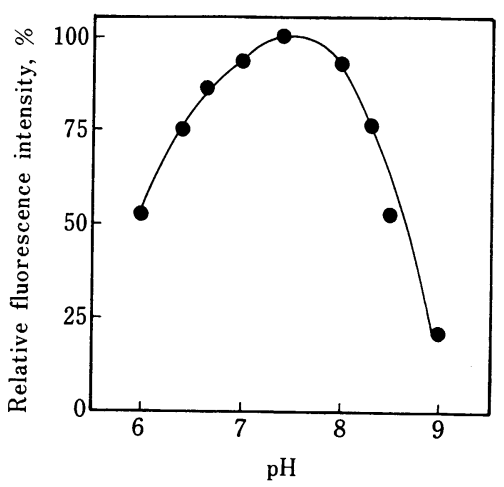

Fig. 3 Effect of $\mathrm{pH}$ on fluorescence intensity

Reactions were carried out for $20 \mathrm{~min}$ at each $\mathrm{pH}$. Allergen (DNP-BSA) concentration : 50 $\mathrm{ng} \mathrm{ml}^{-1}$; Allophycocyanin conjugated allergen (DNP-APC) concentration : $100 \mathrm{ng} \mathrm{ml}^{-1}$

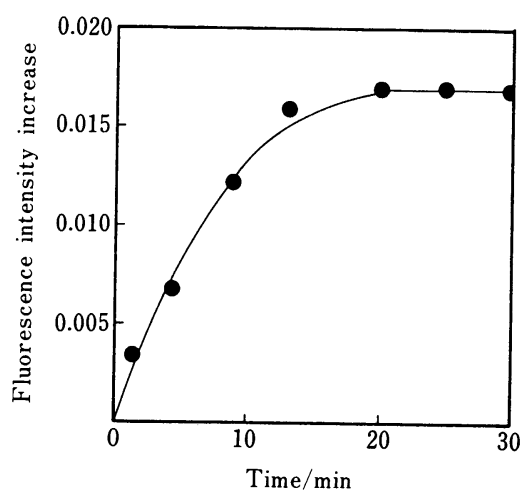

Fig. 4 Time course of the increase in fluorescence intensity with $\operatorname{IgE}$ immobilized membrane Temp. : $27^{\circ} \mathrm{C}$; pH : 7.4; DNP-BSA concentration : $50 \mathrm{ng} \mathrm{ml}^{-1}$; DNP-APC concentration : 100 $\mathrm{ng} \mathrm{\textrm {ml } ^ { - 1 }}$

ろ, 反応時間の経過と共に蛍光強度は増加していくこと が示された (Fig. 4). 20 分以上では蛍光強度はほぼ一 定になることから，反応時間を 20 分に設定し，アレル ゲンの測定を行った．各アレルゲン濃度における蛍光強 度を測定し，アレルゲンの濃度が 0 のとき得られた蛍 光強度を $100 \%$ として, 相対蛍光強度を求めた。 その 結果, アレルゲンの濃度が増すと共に, 相対蛍光強度が 減少することが示された. 蛍光色素標識アレルゲン （DNP-APG）を $100 \mathrm{ng} \mathrm{ml}^{-1}$ の濃度に設定し，アレル ゲンを $10 〜 50 \mathrm{ng} \mathrm{ml}^{-1}$ となるように加えると相対蛍光 


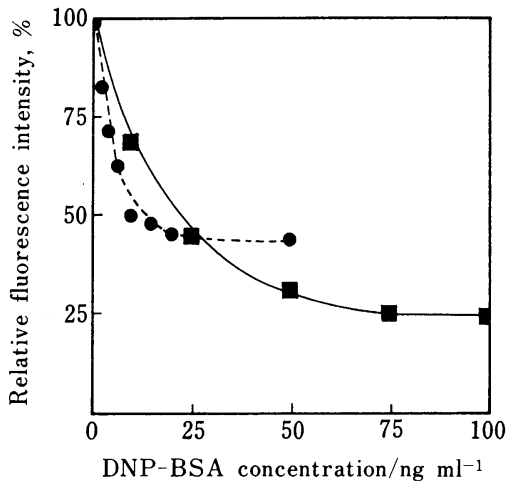

Fig. 5 Relationship between allergen concentration and relative fluorescence intensity

DNP-APC concentration:(ם) $100 \mathrm{ng} \mathrm{ml}^{-1}$, (O) $5 \mathrm{ng} \mathrm{ml}^{-1}$. Other experimental conditions were the same as those for Fig. 4.

強度は $25 \sim 70 \%$ 減少した。

更に, DNP-APC の濃度を $5 \mathrm{ng} \mathrm{m}^{-1}$ にした場合に おいても, 同様に相対蛍光強度が減少することが示され た. 特に, $0 \sim 10 \mathrm{ng} \mathrm{ml}^{-1}$ のアレルゲン濃度範囲におい て相対蛍光強度は直線的に減少し, 相対蛍光強度からア レルゲンの濃度が推定可能であることが示された（Fig. 5). ウシ血清アルブミン，ヒトアルブミンなどのタンパ クやマウス $\mathrm{IgG}$ などを濃度 $5 \mathrm{ng} \mathrm{m}^{-1}$ になるように加 えても, 蛍光強度に変化は見られなかった。このことか ら，本法ではマウス IgE と対応するアレルゲンによる 抗原抗体反忘が起こったときのみ蛍光強度が変化し, そ の相対蛍光強度からアレルゲンが測定可能であることが 示された.

\section{$3 \cdot 3$ 抗体固定化膜の再使用性の検討}

アレルゲン及びアロフィコシアニン標識アレルゲンの 濃度をそれぞれ $5 \mathrm{ng} \mathrm{ml}^{-1}$ に調整し, 蛍光強度を測定し た. 測定後, センサープローブをグリシンー塩酸緩衝液 （pH 2.4）中に浸し，固定化した抗体とアレルゲンを解 離し, 再びアレルゲンの測定を行い再使用性について検 討した. 1 回目の测定時に得られた蛍光強度を $100 \%$ と した場合の各測定での相対蛍光強度を Fig. 6 に示し た. 相対蛍光強度は, 10 回の測定においても $15 \%$ の低 下しか見られず，安定に再使用できることが示された。

以上のように, IgE の抗原抗体反応を利用したオプト ロード型のアレルギーセンサーを作製し，モデルアレル

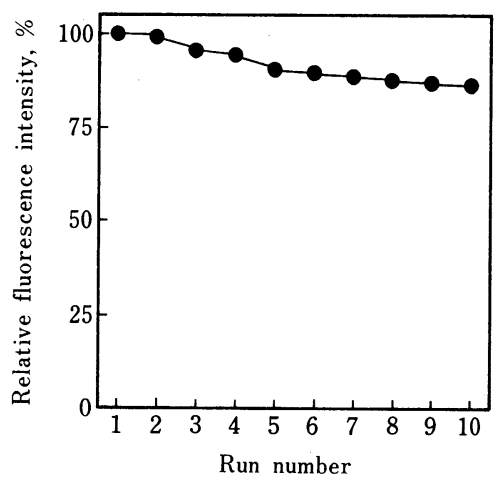

Fig. 6 Reusability of an optrode modified with $\operatorname{IgE}$ immobilized membrane

DNP-BSA concentration : $5 \mathrm{ng} \mathrm{ml}^{-1}$; DNPAPC concentration : $5 \mathrm{ng} \mathrm{ml}^{-1}$. Other experimental conditions were the same as those for Fig. 4.

ゲンとして DNP-BSA を測定することができた．既に 報告されたオプトロード型のセンサーと比べて, 測定に 要する時間も 20 分と短縮され, 感度にも優れ $1 \mathrm{ml}$ 当 たり ng オーダーの測定が可能であった. しかも，抗体 固定化膜は 10 回程度なら再使用可能であることが示さ れた. 今後は, 花粉, ミルク, 卵白などのアレルゲンに 対する IgEを調製して，実際のアレルゲンを検出する ことを目指している.

\section{文献}

1) R. Bose, V. Holford-Strevens, A. H. Sehon: J. Immunol. Methods, 89, 249 (1981).

2) T. Matsunaga, A. Shigematsu, N. Nakamura : Anal. Chem., 61, 2471 (1989).

3) J. S. Schultz, S. Mansouri, I. J. Goldstein : Diabetes Care, 5, 245 ( 1982 ).

4) M. D. Warner: Anal. Chem., 58, 766A (1986).

5) B. J. Tromberg, M. J. Sepaniak, T. Vo-Dinh, G. D. Griffin : Anal. Chem., 59, 1226 (1987).

6) F. V. Bright, T. A. Betts, K. S. Litwiler: Anal. Chem., 62, 1065 (1990).

7) J. R. Little, H. N. Eisen: "Methods in Immunology and Immunochemistry, vol. I", Edited by C. A. Williams, M. W. Chase, p. 128 (1967), (Academic Press, New York).

8) O. H. Lowry, N. J. Rosebrough, A. L. Farr, R. J. Randall : J. Biol. Chem., 193, 265 (1951).

is

Detection of allergen using an optrode modified with immunoglobulin $E$ immobilized membrane. Noriyuki Nakamura and Tadashi Matsunaga (Department 
of Biotechnology, Tokyo University of Agriculture and Technology, 2-24-16, Nakamachi, Koganei-shi, Tokyo 184)

An optrode system based on a competitive binding technique for fluoroimmuoassay was developed. Immunoglobulin $\mathrm{E}$ ( $\mathrm{IgE}$ ) was immobilized on a membrane which covered the edge of an optical fiber. The sensor was exposed to a solution containing dinitrophenylated bovine serum albumin (DNP-BSA) and then allophycocyanin conjugated DNP-BSA was added. A heliumneon $(\mathrm{He}-\mathrm{Ne})$ laser provided an excitation of the binding antigen-antibody complex. The resulting in fluorescence emission was measured using the sensing probe. The fluorescence intensity was proportional to the amount of allophycocyanin conjugated DNP-BSA in the sample. A linear relationship was obtained between the relative fluorescence intensity and the allergen concentration in the range $0 \sim 10 \mathrm{ng} \mathrm{ml}^{-1}$.

(Received July 10, 1990)

\section{Keyword phrases}

detection of allergen; optrode sensor system; immunoglobulin $\mathrm{E}$; fluoroimmunoassay. 